\title{
Severe atrophic gastritis with Helicobacter pylori infection and gastric cancer
}

\author{
Fumiaki Kitahara, Ryoichi Shimazaki, Tadashi Sato, Yuichiro Kojima, Atsuro Morozumi, \\ and Masayuki A. Fujino \\ First Department of Medicine, Yamanashi Medical University, 1110 Shimokato, Tamaho-cho, Nakakoma, Yamanashi 409-3898, Japan
}

\begin{abstract}
:
Background. We conducted a case-control study to evaluate whether patients with severe gastric atrophy (indicated by serum pepsinogen concentration) have a high risk of gastric cancer.

Methods. At the time of diagnosis of gastric cancer, sera from 301 patients (cases) and 602 sex- and age-matched cancer-free individuals (controls) were tested for the presence of antiHelicobacter pylori IgG antibody (HM-CAP enzyme-linked immunoassay [ELISA] kit; Kyowa Medix, Tokyo, Japan) and serum pepsinogen (PG) levels (PG I and II Riabead Kits; Dainabot, Tokyo, Japan). We defined positivity for pepsinogen a pepsinogen $I$ concentration of less than $70 \mathrm{ng} / \mathrm{mL}$ and a PG I/II ratio of less than 3.0. We categorized the subjects according to serum pepsinogen levels and anti-Helicobacter pylori IgG antibody, creating four categories.

Results. Of the 301 cancer cases, 177 had positive serum pepsinogen levels, and $\mathbf{1 7 2}$ were positive for anti-Helicobacter pylori IgG antibody. The category in which subjects had positive serum pepsinogen levels and were negative for antiHelicobacter pylori IgG antibody had the highest proportion (76.9\%) of individuals with gastric cancer and the highest odds ratio (4.20) of the four categories. The odds ratios were $\mathbf{2 . 5 5}$ (95\% confidence interval; $1.92-3.88)$ for positive serum pepsinogen levels and 0.93 (95\% confidence interval; $0.63-1.27)$ for positive anti-Helicobacter pylori IgG antibody.

Conclusion. These results suggest that patients with positive serum pepsinogen levels who are negative for IgG antibody to Helicobacter pylori, constitute a high-risk group for gastric cancer. Helicobacter pylori infection is associated with the development of gastric cancer by providing a suitable environment i.e., severe gastric atrophy, for carcinogenesis of the gastric mucosa.
\end{abstract}

Key words: Helicobacter pylori, pepsinogen, atrophic gastritis, gastric cancer, case-control study

Offprint requests to: $\mathrm{F}$. Kitahara

Received for publication on Mar. 20, 1998; accepted on Aug. 20, 1998

\section{Introduction}

Gastric cancer is one of the leading causes of mortality in Japan and many risk factors have been implicated [1]. Many case-control studies have found an increased cumulative risk of gastric cancer and precancerous conditions in individuals with Helicobacter pylori antibodies [2-4]. Based on this epidemiologic evidence, the World Health Organization (WHO) International Agency for Research on Cancer concluded: There is sufficient evidence that $H$. pylori has a causal role in the chain of events leading to gastric cancer [5].

However, there are several problems with regard to the association between $H$. pylori infection and gastric cancer. First, there is no infected model of $H$. pylori with subsequent gastric cancer, and the mechanism of gastric cancer growth has not been made clear at the gene level. Secondly, atrophy and metaplasia are implicated in the pathogenesis of gastric cancer of the intestinal type, whereas gastric cancer of the diffuse type does not clearly coexist with atrophy and metaplasia.

Several reports have shown that the extent of atrophy in gastric mucosa without $H$. pylori infection does not increase with age [6-12]. Mucosa with severe atrophic gastritis is, however, associated with an increased risk of gastric cancer [6-9,13-18]. Therefore, it is now suggested that $H$. pylori infection, through the development of atrophic gastritis, is an indirect cause of gastric cancer.

We conducted a case-control study to evaluate the effect of $H$. pylori infection on the development of gastric cancer. We also investigated the risk of gastric cancer in patients with severe atrophic gastritis.

Subjects and methods

Study population

Between April 1989 and March 1997, 521 patients diagnosed with gastric cancer were admitted to the First 
Department of Medicine, Yamanashi Medical University Hospital, in Yamanashi, Japan. Patients with multiple gastric cancers $(n=65)$ were excluded from our analysis, because the evaluation of tumor characteristics becomes complicated. Twenty-five patients who had previously undergone partial gastrectomy were also excluded, as atrophy of the gastric mucosa was marked in the gastric remnant, and its extent depended on the interval after surgery. Blood samples of 130 patients had not been stored at the time of diagnosis. Accordingly, 301 patients ( 213 men, 88 women, mean age at 64 years) were selected as case patients. Blood samples were drawn at the time of diagnosis in the 301 cases, and the separated sera were individually stored at less than $-80^{\circ} \mathrm{C}$ until tested. Control subjects $(n=602)$ were selected from among cancer-free, non-peptic ulcer, and non-gastric remnant patients determined by gastroscopy during health check-ups carried out at Yamanashi Koseiren Medical Center. The control subjects were matched to the cases according to sex and age (within 3 years). The blood samples for routine laboratory tests at the health check-up were drawn after the patients had fasted, and aliquots of the separated sera were individually stored at less than $-80^{\circ} \mathrm{C}$ until tested. We obtained 301 matched sets with one case and two controls. The study was accepted by the Ethics Committee of the Institution, and all participating patients gave their informed consent.

\section{Serological test}

H. pylori infection was determined by testing for the presence of anti-H. pylori $\operatorname{IgG}$ antibody, using an HM-CAP enzyme-linked immunoassay (ELISA) kit (Kyowa Medix, Tokyo, Japan), and subjects with a titer higher than 2.2 were considered positive for $H$. pylori infection. Serum pepsinogen (PG) concentrations were measured using pepsinogen I and II Riabead Kits (Dainabot, Tokyo, Japan), a modified radioimmunoassay method described previously [15]. We regarded as PG-positive those subjects with a PG I concentration of less than $70 \mathrm{ng} / \mathrm{ml}$ and a pepsinogen I: II ratio (I/II ratio) of less than 3.0 [16].

\section{Methods}

We categorized the subjects according to their serum PG concentration and anti-H. pylori IgG antibody titer (Table 1), creating four categories. Category A, positive for serum PG concentration and anti-H. pylori IgG antibody; category $\mathrm{B}$, negative for serum PG concentration and anti-H. pylori $\mathrm{IgG}$ antibody; category C, positive for serum PG concentration and negative for anti-H. pylori IgG antibody; and category $\mathrm{D}$, negative for serum PG concentration and positive for anti- $H$.
Table 1. Four categories of subjects (cases and controls) based on serum pepsinogen concentration and antiHelicobacter pylori antibody titer

\begin{tabular}{lcc}
\hline & Positive PG & Negative PG \\
\hline Positive H. pylori antibody & Category A & Category D \\
Negative H. pylori antibody & Category C & Category B \\
\hline
\end{tabular}

Positive PG, Subjects with serum pepsinogen (PG) I concentration less than $70 \mathrm{ng} / \mathrm{ml}$ and a PG I/II ratio of less than 3.0; negative PG, subjects with serum PG I concentration of more than $70 \mathrm{ng} / \mathrm{ml}$ or PG I/II ratio of more than 3.0; positive $H$. pylori antibody, subjects with a titer of more than 2.2; Negative $H$. pylori antibody, subjects with a titer of less than 2.1

pylori IgG antibody. We compared mean age, percentage of patients with gastric cancer to total subjects, and the odds ratios for each of the four categories, conducting a case-control study to evaluate the effects of $H$. pylori infection and atrophic gastritis (indicated by serum PG concentration), on the risk of gastric cancer.

The statistical calculations were carried out with a statistical software package (Stat view II; Abacus Concepts, Berkeley, CA, USA). Data values are summarized as means $\pm \mathrm{SD}$. Differences in mean age, serum PG I concentration, PG II concentration, and PG I/II ratio between the cases and controls were analyzed by the Mann-Whitney U-test. Pearson's $\chi^{2}$ test was used to compare the prevalence of $H$. pylori infection and positive serum PG in cases and controls. The subjects mean ages in the categories were compared using the Mann-Whitney U-test. A matched case and control study design was used to identify cases and controls for the serum test. Odds ratios (OR), which approximate the relative risk, with $95 \%$ confidence intervals (CI) were determined using the Mantel-Haenzel method. Probability values less than 0.05 were considered significant.

\section{Results}

\section{Gastric cancer cases}

The 301 gastric cancer cases consisted of 213 men and 88 women, with a mean age of 64.0 years. We categorized the cases into two each classes by age, sex, and depth of invasion the (the characteristics of these subgroup analyses are shown in Table 2). There was no significant difference in mean age between the men and the women. We classified depth of invasion as "early" or "advanced" stage. Early stage gastric carcinoma was defined as tumor localized at the deepest level within the submucosa, and advanced stage gastric carcinoma as tumor invading the muscularis propria or beyond. We 
Table 2. Characteristics of cases (patients with gastric cancer)

\begin{tabular}{lcccccc}
\hline Subgroup & Number $(n)$ & Mean age (years) & Mean PG I & Mean PG I/II & PG-positive $^{\mathrm{a}}$ & H. pylori-positive $^{\mathrm{a}}$ \\
\hline All cases & 301 & 64.2 & 52.8 & 22.6 & $58.8 \%$ & $57.1 \%$ \\
Sex & & & & & & \\
$\quad$ Male & 213 & 64.1 & 51.1 & 2.6 & $61.0 \%$ & $63.4 \% *$ \\
$\quad$ Female & 88 & 64.4 & 56.8 & 2.7 & $53.4 \%$ & $42.0 \%$ \\
$\quad \begin{array}{l}\text { Depth of invasion } \\
\quad \text { Early stage }\end{array}$ & 190 & 64.9 & 54.4 & 2.8 & $54.7 \%$ & $60.5 \%$ \\
$\quad \begin{array}{l}\text { Advanced stage } \\
\text { Age (years) }\end{array}$ & 111 & 62.9 & 50.3 & 2.5 & $65.8 \%$ & $51.4 \%$ \\
$\quad<59$ & 85 & 48.4 & 54.4 & 2.8 & $52.9 \%$ & $58.8 \%$ \\
$\quad \geq 60$ & 216 & 70.4 & 52.3 & 2.6 & $61.1 \%$ & $56.5 \%$ \\
\hline
\end{tabular}

$* P<0.05$ compared with females by chi-square test

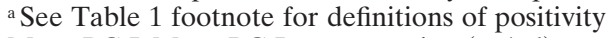

Mean PG I, Mean PG I concentration (ng/ml); mean PG I/II, mean ratio of serum PG II concentration to serum PG I concentration; PG-positive, percentage of subjects positive for serum PG; H. pylori-positive, percentage of subjects with seropositivity for anti- $H$. pylori antibody; early stage, early gastric cancer, defined as that in which tumor is localized as the deepest within the submucosa; advanced stage, advanced gastric cancer, defined as that with the tumor invading the muscularis propria or beyond

did not find any difference in mean age between patients with early stage gastric carcinoma and those with advanced stage. There were no significant differences in mean serum PG I concentrations and PG I/II ratios between either men and women, patients with early or advanced stage gastric carcinoma or patients aged less than 59 years and those aged more than 60 years (MannWhitney U-test). We also found no differences in the percentages of patients who were PG-positive between men and women, between early stage and advanced stage gastric carcinoma, or between those aged less than 59 years and those aged more than 60 years (chi-square test). Men had a significantly higher positivity rate for $H$. pylori infection than women (chi-square test). There were no significant differences in $H$. pylori infection positivity rates between patients with early stage and advanced stage gastric carcinoma, or between those aged less than 59 years and those aged more than 60 years (chi-square test).

\section{Comparison of cases and controls}

The relevant characteristics of the 301 cases and 602 controls are shown in Table 3 . We did not find any differences in mean serum PG I and PG II concentration between cases and controls. Cases had significantly lower PG I/II ratios than controls $(P<0.001$, MannWhitney U-test) and significantly higher rates for positive serum PG concentration than controls $(P<0.001$, chi-square test). There was no significant difference in the percentages positive for $H$. pylori infection between cases $(57.1 \%)$ and controls $(61.6 \%)$ (chi-square test).

\section{Association between serum $P G$ and $\mathrm{H}$. pylori antibody}

Table 4 shows the association between serum PG and $H$. pylori antibody in the cases.
Table 3. Characteristics of cases and controls

\begin{tabular}{lcc}
\hline Characteristic & Cases & Controls \\
\hline No of subjects & 301 & 602 \\
Sex ratio (m/f) & $213 / 88$ & $426 / 176$ \\
Mean age \pm SD (years) & $64.2 \pm 12.2$ & $63.8 \pm 10.6$ \\
PG I (ng/ml) & $52.8 \pm 47.7$ & $56.1 \pm 31.3$ \\
PG II (ng/ml) & $19.9 \pm 13.5$ & $17.5 \pm 10.3$ \\
PG I/II ratio & $2.6 \pm 1.5^{*}$ & $3.9 \pm 2.4$ \\
Positivity rate for PG (\%) & $177(58.8 \%)^{* *}$ & $216(35.9 \%)$ \\
Positivity rate for & $172(57.1 \%)$ & $371(61.6 \%)$ \\
$\quad$ H. pylori $(\%)$ & &
\end{tabular}

* $P<0.001$ compared with controls by Mann-Whitney U-test;

$* * P<0.001$ compared with controls by chi-square test

Positive PG rate, percentage of subjects positive for serum PG; positive $H$. pylori rate, percentage of subjects with seropositivity for anti- $H$. pylori antibody

The association between serum PG and $H$. pylori antibody in controls is shown in Table 5. The mean ages of controls increased in the order category B to $\mathrm{D}$ to $\mathrm{A}$ to $\mathrm{C}$. It is assumed that this order was strongly related to the development of atrophy in gastric mucosa.

Table 6 summarizes the association between serum PG and H. pylori antibody in cases and controls. Of the four categories, category $\mathrm{C}$ had the highest percentage of gastric cancer cases $(64.3 \%)$. The proportion of gastric cancer cases increased in the order of B to D to A to C. This order was also related to increasing atrophy in the gastric mucosa. Thus, category $\mathrm{C}$, with low serum PG concentration and negative for $H$. pylori $\mathrm{IgG}$ antibody, is a high risk group for gastric cancer. The odds ratios for the categories are also shown in Table 6. Category $\mathrm{C}$ had the highest odds ratio $(4.20$; $95 \%$ CI, $2.66-$ 6.04) of the four categories. 
Table 4. Association between serum PG concentration and H. pylori antibody in cases

\begin{tabular}{clc}
\hline & Positive PG & Negative PG \\
\hline No positive for $H$. pylori antibody $(\%)$ & $94(31.2 \%)$ & $78(25.9 \%)$ \\
Mean age \pm SD (years) & Category A & Category D \\
& $65.5 \pm 10.3$ & $61.5 \pm 12.4$ \\
No negative for $H$. pylori antibody $(\%)$ & $83(27.6 \%)$ & $46(15.3 \%)$ \\
Mean age \pm SD (years) & Category C & Category B \\
& $65.8 \pm 13.0$ & $63.2 \pm 13.5$ \\
\hline
\end{tabular}

Positive PG, Subjects with serum PG I concentration less than $70 \mathrm{ng} / \mathrm{ml}$ and PG I/II ratio less than 3.0; negative PG, subjects with serum PG I concentration more than $70 \mathrm{ng} / \mathrm{ml}$ or PG I/II ratio more than 3.0; positive for H. pylori antibody, subjects with titer more than 2.2; negative for $H$. pylori antibody, subjects with a titer less than 2.1

Table 5. Association between serum PG concentration and H. pylori antibody in controls

\begin{tabular}{ccc}
\hline & Positive PG & Negative PG \\
\hline No positive for $H$. pylori antibody $(\%)$ & $170(28.2 \%)$ & $201(33.4 \%)$ \\
Mean age \pm SD (years) & Category A & Category D \\
& $66.7 \pm 6.9$ & $62.8 \pm 9.5$ \\
No negative for $H$. pylori antibody $(\%)$ & $46(7.6 \%)$ & $185(30.8 \%)$ \\
Mean age \pm SD (years) & Category C & Category B \\
& $67.0 \pm 8.3$ & $58.3 \pm 13.0$ \\
\hline
\end{tabular}

Table 6. Proportion of gastric cancer cases to total number of subjects, and odds ratios (ORs) for each category

\begin{tabular}{lccc}
\hline Category & Gastric cancer cases (\%) & OR & $95 \%$ CI \\
\hline A & $35.6 \%$ & 1.21 & $0.85-1.72$ \\
B & $19.9 \%$ & 0.36 & $0.25-0.53$ \\
C & $64.3 \%$ & 4.20 & $2.66-6.04$ \\
D & $28.0 \%$ & 0.77 & $0.54-1.10$
\end{tabular}

See Table 1 for explanation of categories A-D

CI, Confidence interval

\section{Association between $\mathrm{H}$. pylori infection and cancer}

The matched odds ratio of $H$. pylori infection and gastric cancer was 0.93 (95\% CI, 0.63-1.21; Table 7). No significant association between $H$. pylori infection and gastric cancer was observed. The results of subgroup analyses by age, sex, and depth of tumor invasion are also shown in Table 7 . The odds ratio in the group less than 59 years was high $(1.53 ; 95 \%$ CI, 0.91-2.59).

\section{Association between positive serum PG concentration and cancer}

The matched odds ratios for positive serum PG concentration and gastric cancer was 2.55 (95\% CI, 1.92-3.38; Table 7). Positive serum PG concentration was signifi- cantly associated with gastric cancer. The results of subgroup analyses are also shown in Table 7. Significant associations between positive serum PG concentration and cancer were observed in all subgroups.

\section{Discussion}

In recent years, there have been many studies of the relationship between $H$. pylori infection and gastric cancer [2-4,19-35]. The major findings of these 21 studies (including this study) are compared in Table 8.

Nine of the above studies reported a significant association between $H$. pylori infection and gastric cancer (OR, range, 2.6-13.3). In 19 of the studies, H. pylori infection was determined by serum $\mathrm{IgG}$ antibody to $H$. pylori. Ten of the studies were nested case-control studies, and the other 11 were cross-sectional case-control studies. Forman et al. [36] reported a significant trend towards an increased OR with increasing time between blood sample collection and cancer diagnosis, by multivariate analysis. The nested case-control studies seemed to show high ORs because the blood samples were collected long before the cancer diagnosis.

Five of the ten nested case-control studies showed a positive association between $H$. pylori infection and gastric cancer. Of these five studies, three were conducted in countries with a low prevalence of $H$. pylori 
Table 7. Odds ratios for gastric cancer according to anti-H. pylori antibody and serum PG concentration

\begin{tabular}{lcc}
\hline & $\begin{array}{c}\text { Positive for H. pylori antibody } \\
\text { Odds ratio }(95 \% \mathrm{CI})\end{array}$ & $\begin{array}{c}\text { Positive PG } \\
\text { Odds ratio (95\% CI) }\end{array}$ \\
\hline $\begin{array}{l}\text { All cases } \\
\text { Sex }\end{array} \quad 0.93(0.63-1.27)$ & $2.55(1.92-3.38)$ \\
$\quad \begin{array}{l}\text { Male } \\
\text { Female }\end{array}$ & $0.87(0.61-1.62)$ & $2.77(1.98-3.86)$ \\
$\begin{array}{l}\text { Depth of invasion } \\
\quad \text { Early stage } \\
\quad \text { Advanced stage }\end{array}$ & $0.74(0.44-1.24)$ & $2.11(1.26-3.53)$ \\
$\begin{array}{l}\text { Age (years) } \\
\quad<59\end{array}$ & $0.95(0.68-1.33)$ & $2.16(1.56-3.80)$ \\
$\quad \geq 60$ & $0.66(0.44-0.98)$ & $3.43(2.28-5.17)$ \\
\hline
\end{tabular}

Table 8. Comparison of odds ratios for association between H. pylori seropositivity and gastric cancer in 21 case-control studies

\begin{tabular}{|c|c|c|c|c|c|c|c|c|c|}
\hline Author & Country & Design & $\begin{array}{l}\text { Time } \\
\text { (years) }\end{array}$ & $\begin{array}{c}\text { H. pylori }(+) \\
\text { Cases }\end{array}$ & $\begin{array}{l}\text { H. pylori }(+) \\
\text { Controls }\end{array}$ & OR & $\mathrm{CI}$ & Age & Assess \\
\hline Parsonnet [4] & USA & NCCS & 14.2 & $84.4 \%$ & $60.6 \%$ & 3.6 & $1.8-7.3$ & 54 & $\mathrm{IgG}$ \\
\hline Nomura [3] & J-Ame & NCCS & 13 & $94 \%$ & $76 \%$ & 6.0 & $2.1-17.3$ & 59 & $\mathrm{IgG}$ \\
\hline Forman [2] & UK & NCCS & 6 & $69 \%$ & $47 \%$ & 2.8 & $1.0-8.0$ & 54 & $\mathrm{IgG}$ \\
\hline Talley [33] & USA & NCCS & 3.7 & $52 \%$ & $38 \%$ & 2.7 & $1.4-5.0$ & 63 & $\mathrm{IgG}$ \\
\hline Hansson [25] & Sweden & NCCS & 2.6 & $80 \%$ & $61 \%$ & 2.6 & $1.4-5.0$ & 67 & $\mathrm{IgG}$ \\
\hline Lin [30] & Taiwan & NCCS & 3.1 & $69 \%$ & $59 \%$ & 1.6 & $0.7-2.6$ & 58 & $\mathrm{IgG}$ \\
\hline Blaser [23] & $\mathrm{J}$-Ame & NCCS & 21 & $87.4 \%$ & $77.7 \%$ & 1.9 & $0.9-4.0$ & 59 & $\operatorname{cag} \mathrm{A}$ \\
\hline Aromaa [20] & Finland & NCCS & 13 & $86.9 \%$ & $82.9 \%$ & 1.5 & $0.7-3.2$ & 62 & $\mathrm{IgG}$ \\
\hline Webb [34] & China & NCCS & 2.4 & $54.1 \%$ & $56.1 \%$ & 0.9 & $0.6-1.5$ & 61 & $\mathrm{IgG}$ \\
\hline Watanabe [32] & Japan & NCCS & 3.2 & $91.1 \%$ & $75.6 \%$ & 1.8 & $0.6-5.7$ & 63 & $\mathrm{IgG}$ \\
\hline $\begin{array}{l}\text { Archimen- } \\
\text { dinitis [19] }\end{array}$ & Greece & CSCCS & & $72.3 \%$ & $68 \%$ & 1.2 & $0.5-3.0$ & 62 & $\mathrm{IgG}$ \\
\hline Fukuda [24] & Japan & CSCCS & & $76.2 \%$ & $73.9 \%$ & 1.0 & $0.7-1.5$ & 57 & $\mathrm{IgG}$ \\
\hline Kikuchi [27] & Japan & CSCCS & & $88.6 \%$ & $39 \%$ & 13.3 & $5.3-35.6$ & 34 & $\operatorname{IgG}$ \\
\hline Asaka [21] & Japan & CSCCS & & $87.2 \%$ & $58.5 \%$ & 2.4 & $1.2-4.8$ & 60 & $\mathrm{IgG}$ \\
\hline Kato [26] & Japan & CSCCS & & $70.8 \%$ & $68.5 \%$ & 1.1 & $0.7-1.6$ & 62 & IgG \\
\hline Kokkola [29] & Finland & CSCCS & & $72 \%$ & $44 \%$ & 3.3 & $1.4-7.5$ & 37 & hist \\
\hline Barreto [22] & Japan & CSCCS & & $82 \%$ & $60 \%$ & 3.0 & $1.7-5.3$ & 56 & $\mathrm{IgG}$ \\
\hline $\operatorname{Kim}[28]$ & Korea & CSCCS & & $60 \%$ & $51.9 \%$ & 1.4 & $0.9-2.2$ & 57 & hist \\
\hline Kuipers [35] & Italy & CSCCS & & $77 \%$ & $79 \%$ & 0.9 & $0.3-2.2$ & 67 & $\operatorname{IgG}$ \\
\hline Lopez [31] & Mexico & CSCCS & & $82.5 \%$ & $87.5 \%$ & 1.4 & $0.7-2.8$ & 56 & $\mathrm{IgG}$ \\
\hline Our study & Japan & CSCCS & & $57.1 \%$ & $61.6 \%$ & 0.9 & $0.6-1.2$ & 64 & $\mathrm{IgG}$ \\
\hline
\end{tabular}

Time, Interval (years) between blood sample collection and gastric cancer diagnosis; H. pylori (+) cases, percentage of patients positive for $H$. pylori infection among-gastric cancer cases; H. pylori $(+)$ controls, percentage of subjects positive for $H$. pylori infection among matched controls; OR, odds ratio; CI, confidence interval; age, mean age of gastric cancer cases; assess, assessment of $H$. pylori infection; J-Ame, Japanese American; NCCS, nested case-control study; CSCCS, cross-sectional case-control study; IgG, anti-H. pylori IgG antibody; hist, histopathology

infection (United States and United Kingdom) [37]. The study of Nomura et al. [3] reported a high seropositivity rate of $H$. pylori infection in cases, and the study of Hansson et al. [25] reported a low seropositivity rate of $H$. pylori infection in their matched controls. The remaining five nested case-control studies were conducted in countries with a high prevalence of $H$. pylori infection (Japan, Taiwan, China, and Finland) [37]. Four of the 11 cross-sectional case-control studies reported a positive association between $H$. pylori infection and gastric cancer. Two of these four studies were conducted in a younger population (aged less than 50 years). Case-control studies in young populations have high ORs as the seropositivity rate of $H$. pylori infection in the matched controls is relatively low. The study of Barreto and colleagues [22] had a low seropositivity rate of $H$. pylori infection in controls, and that of Asaka and colleagues [21] had a high seropositivity rate of $H$. pylori infection in cases. Two factors that influence the OR are the prevalence rate of the risk factor in the population, and the interval between serum collection and diagnosis. 
Our results do not support the hypothesis that $H$. pylori infection plays a role in gastric cancer carcinogenesis, as our study showed a low prevalence of $H$. pylori infection in the gastric cancer cases. Most cancer cases with seronegativity for $H$. pylori infection belonged to category $\mathrm{C}$ (positive for serum PG concentration and negative for $H$. pylori infection). Category $\mathrm{C}$ had the highest percentage of gastric cancer cases of all categories. Most of the subjects in category $\mathrm{C}$ had extensive mucosal atrophy (indicated by low PG I and low PG I/II ratio), and this may cause spontaneous loss of $H$. pylori from the stomach. Our results suggested the following theory. First, $H$. pylori infection caused anti- $H$. pylori IgG antibody seropositivity, in result subjects in category B changed to those in category D. Next, chronic gastritis due to $H$. pylori infection, caused extensive mucosal atrophy, in result subjects in category D changed to those in category A. Finally, the extensive mucosal atrophy led to the spontaneous loss of $H$. pylori from the stomach, in result most of subjects in category A changed to those in category C. Indeed, the gastric mucosa in category $\mathrm{C}$ subjects showed the greatest extent of mucosal atrophy, due to $H$. pylori infection, and subjects in this category had the highest risk of gastric cancer among our four categories. Previous studies have also suggested that loss of $H$. pylori colonization and subsequent loss of seropositivity may occur frequently in conditions such as severe atrophic gastritis and intestinal metaplasia [24,32,38]. Thus, false-negative results for $H$. pylori infection may have been frequent in gastric cancer cases in blood samples taken at the time of cancer diagnosis, because loss of seropositivity may have occurred in the gastric cancer patients with severe gastric atrophy.

Serum PG concentrations (low PG I and low PG I/II ratio) are considered to be a reliable marker of chronic atrophic gastritis [18,39-41], and are useful for the screening of gastric cancer [6-9,13-18]. The severity of atrophic gastritis is well correlated with serum PG I concentration and with PG I/II ratio [39,42]. Therefore, atrophic gastritis was associated with a significantly increased risk of gastric cancer (OR, $6.59 ; 95 \%$ CI, 3.45-12.57) in our study, as we used the serum PG concentration as a marker of extensive mucosal atrophy.

In conclusion, our results suggest that $H$. pylori infection leads to severe atrophic gastritis and intestinal metaplasia in the gastric mucosa, with gastric cancer eventually occurring in this environment. Therefore, it appears that $H$. pylori infection is one of the indirect causes of gastric cancer, via the development of atrophic gastritis. Individuals who have severe atrophy and intestinal metaplasia in the gastric mucosa have the highest risk of gastric cancer. False-negative assess- ments of $H$. pylori infection may be frequent in this high-risk group.

H. pylori seems not to act as an initiator in the development of gastric cancer, but as a promoter in the progression from normal mucosa to severe atrophy. However, it seems that $H$. pylori infection alone is neither necessary nor sufficient for the development of gastric cancer. Dietary factors, such as excessive salt intake and diets low in fresh fruits and vegetables; smoking; and genetic factors may still play important roles in gastric cancer carcinogenesis [30,43-47]. The role of $H$. pylori infection in the complex multifactorical carcinogenesis of gastric cancer needs to be explored further in the light of the multistep theory of gastric carcinogenesis.

\section{References}

1. Correa P. Human gastric carcinogenesis: A multistep and multifactorial process. First American Cancer Society Award Lecture on Cancer Epidemiology and Prevention. Cancer Res 1992;52:6735-40.

2. Forman D, Newell DG, Fullerton F, Yarnell JW, Stacey AR, Wald N, et al. Association between infection with Helicobacter pylori and risk of gastric cancer: Evidence from a prospective investigation. BMJ 1991;302:1302-5.

3. Nomura A, Stemmermann GN, Chyou PH, Kato I, Perez PG, Blaser MJ. Helicobacter pylori infection and gastric carcinoma among Japanese Americans in Hawaii. N Engl J Med 1991; 325:1132-6.

4. Parsonnet J, Friedman GD, Vandersteen DP, Chang Y, Vogelman JH, Orentreich N, et al. Helicobacter pylori infection and the risk of gastric carcinoma. N Engl J Med 1991;325:112731.

5. International Agency for Research on Cancer. Schistosomiasis, liver flukes and Helicobacter pylori. IARC Monogr. Eval. Carcinog. Risks Hum 1994;61:177-240.

6. Varis K, Kekki M, Harkonen M, Sipponen P, Samloff IM. Serum pepsinogen I and serum gastrin in the screening of atrophic pangastritis with high risk of gastric cancer. Scand J Gastroenterol Suppl 1991;186:117-23.

7. Matsukura N, Onda M, Tokunaga A, Fujita I, Okuda T, Mizutani T, et al. Significance of serum markers pepsinogen I and II for chronic atrophic gastritis, peptic ulcer, and gastric cancer. J Clin Gastroenterol 1993;17:146-50.

8. Farinati F, Di MF, Plebani M, Cielo R, Fanton MC, Valiante F, et al. Pepsinogen $\mathrm{A} /$ pepsinogen $\mathrm{C}$ or pepsinogen $\mathrm{A}$ multiplied by gastrin in the diagnosis of gastric cancer? Ital $\mathrm{J}$ Gastroenterol 1991;23:194-6.

9. You WC, Blot WJ, Zhang L, Kneller RW, Li JY, Jin ML, et al. Serum pepsinogens in relation to precancerous gastric lesions in a population at high risk for gastric cancer. Cancer Epidemiol Biomarkers Prev 1993;2:113-7.

10. Fukao A, Hisamichi S, Ohsato N, Fujino N, Endo N, Iha M. Correlation between the prevalence of gastritis and gastric cancer in Japan. Cancer Causes Control 1993;4:17-20.

11. Fukao A, Komatsu S, Tsubono Y, Hisamichi S, Ohori H, Kizawa $\mathrm{T}$, et al. Helicobacter pylori infection and chronic atrophic gastritis among Japanese blood donors: A cross-sectional study. Cancer Causes Control 1993;4:307-12.

12. Tsugane S, Kabuto M, Imai H, Gey F, Tei Y, Hanaoka T, et al. Helicobacter pylori, dietary factors, and atrophic gastritis in five Japanese populations with different gastric cancer mortality. Cancer Causes Control 1993;4:297-305. 
13. Kato I, Tominaga S, Ito Y, Kobayashi S, Yoshii Y, Matsuura A, et al. Atrophic gastritis and stomach cancer risk: Cross-sectional analyses. Jpn J Cancer Res 1992;83:1041-6.

14. Tatsuta M, Iishi H, Nakaizumi A, Okuda S, Taniguchi H, Hiyama $\mathrm{T}$, et al. Fundal atrophic gastritis as a risk factor for gastric cancer. Int J Cancer 1993;53:70-4.

15. Ichinose M, Miki K, Furihata C, Kageyama T, Hayashi R, Niwa $\mathrm{H}$, et al. Radioimmunoassay of serum group I and group II pepsinogens in normal controls and patients with various disorders. Clin Chim Acta 1982;126:183-91.

16. Miki K, Ichinose M, Ishikawa KB, Yahagi N, Matsushima M, Kakei N, et al. Clinical application of serum pepsinogen I and II levels for mass screening to detect gastric cancer. Jpn J Cancer Res 1993;84:1086-90.

17. Huang SC, Miki K, Furihata C, Ichinose M, Shimizu A, Oka H. Enzyme-linked immunosorbent assays for serum pepsinogens I and II using monoclonal antibodies - with data on peptic ulcer and gastric cancer. Clin Chim Acta 1988;175:37-50.

18. Sitas F, Smallwood R, Jewell D, Millard PR, Newell DG, Meuwissen SG, et al. Serum anti-Helicobacter pylori IgG antibodies and pepsinogens $\mathrm{A}$ and $\mathrm{C}$ as serological markers of chronic atrophic gastritis. Cancer Epidemiol Biomarkers Prev 1993;2:11923.

19. Archimandritis A, Bitsikas J, Tjivras M, Anastasakou E, Tsavaris $\mathrm{N}$, Kalogeras D, et al. Non-cardia gastric adenocarcinoma and Helicobacter pylori infection. Ital J Gastroenterol 1993;25:368-71.

20. Aromaa A, Kosunen TU, Knekt P, Maatela J, Teppo L, Heinonen OP, et al. Circulating anti-Helicobacter pylori immunoglobulin A antibodies and low serum pepsinogen I level are associated with increased risk of gastric cancer. Am J Epidemiol 1996;144:142-9.

21. Asaka M, Kato M, Kudo M, Katagiri M, Nishikawa K, Yoshida J, et al. Relationship between Helicobacter pylori infection, atrophic gastritis and gastric carcinoma in a Japanese population. Eur J Gastroenterol Hepatol 1995;7:7-10.

22. Barreto ZR, Maruyama M, Kato Y, Aizu K, Ohta H, Takekoshi $\mathrm{T}$, et al. Significance of Helicobacter pylori infection as a risk factor in gastric cancer: Serological and histological studies. J Gastroenterol 1997;32:289-94.

23. Blaser MJ, Perez PG, Kleanthous H, Cover TL, Peek RM, Chyou $\mathrm{PH}$, et al. Infection with Helicobacter pylori strains possessing cagA is associated with an increased risk of developing adenocarcinoma of the stomach. Cancer Res 1995;55:2111-5.

24. Fukuda H, Saito D, Hayashi S, Hisai H, Ono H, Yoshida S, et al. Helicobacter pylori infection, serum pepsinogen level and gastric cancer: A case-control study in Japan. Jpn J Cancer Res 1995; 86:64-71.

25. Hansson LE, Engstrand L, Nyren O, Evans DJ, Lindgren A, Bergstrom R, et al. Helicobacter pylori infection: Independent risk indicator of gastric adenocarcinoma. Gastroenterology 1993; 105:1098-103.

26. Kato S, Onda M, Matsukura N, Tokunaga A, Matsuda N, Yamashita K, et al. Genetic polymorphisms of the cancer related gene and Helicobacter pylori infection in Japanese gastric cancer patients. An age and gender matched case-control study. Cancer 1996;77:1654-61.

27. Kikuchi S, Wada O, Nakajima T, Nishi T, Kobayashi O, Konishi $\mathrm{T}$, et al. Serum anti-Helicobacter pylori antibody and gastric carcinoma among young adults. Research Group on Prevention of Gastric Carcinoma among Young Adults. Cancer 1995;75:2789_ 93.

28. Kim HY, Cho BD, Chang WK, Kim DJ, Kim YB, Park CK, et al. Helicobacter pylori infection and the risk of gastric cancer among the Korean population. J Gastroenterol Hepatol 1997;12:1003.

29. Kokkola A, Valle J, Haapiainen R, Sipponen P, Kivilaakso E, Puolakkainen P. Helicobacter pylori infection in young patients with gastric carcinoma. Scand J Gastroenterol 1996;31:643-7.

30. Lin JT, Wang LY, Wang JT, Wang TH, Yang CS, Chen CJ. A nested case-control study on the association between Helicobacter pylori infection and gastric cancer risk in a cohort of 9775 men in Taiwan. Anticancer Res 1995;15:603-6.

31. Lopez CL, Fernandez OC, Robles DG, Rascon PR, Ramirez IT. Helicobacter pylori infection and gastric cancer in Mexico. A challenge for prevention and population control. Rev Gastroenterol Mex 1997;62:22-8.

32. Watanabe Y, Kurata JH, Mizuno S, Mukai M, Inokuchi H, Miki $\mathrm{K}$, et al. Helicobacter pylori infection and gastric cancer. A nested case- control study in a rural area of Japan. Dig Dis Sci 1997;42:1383-7.

33. Talley NJ, Zinsmeister AR, Weaver A, DiMagno EP, Carpenter HA, Perez PG, et al. Gastric adenocarcinoma and Helicobacter pylori infection. J Natl Cancer Inst 1991;83:1734-9.

34. Webb PM, Yu MC, Forman D, Henderson BE, Newell DG, Yuan JM, et al. An apparent lack of association between Helicobacter pylori infection and risk of gastric cancer in China. Int $\mathrm{J}$ Cancer 1996;67:603-7.

35. Kuipers EJ, Klinkenberg KE, Vandenbroucke GC, Appelmelk BJ, Schenk BE, Meuwissen SG. Role of Helicobacter pylori in the pathogenesis of atrophic gastritis. Scand J Gastroenterol Suppl 1997;223:28-34.

36. Forman D, Webb P, Parsonnet J. H. pylori and gastric cancer. Lancet 1994;343:243-4.

37. The Eurogast Study Group. An international association between Helicobacter pylori infection and gastric cancer. Lancet 1993; 341:1359-62.

38. Karnes WE Jr, Samloff IM, Siurala M, Kekki M, Sipponen P, Kim SW, et al. Positive serum antibody and negative tissue staining for Helicobacter pylori in subjects with atrophic body gastritis. Gastroenterology 1991;101:167-74.

39. Samloff IM, Varis K, Ihamaki T, Siurala M, Rotter JI. Relationships among serum pepsinogen I, serum pepsinogen II, and gastric mucosal histology. A study in relatives of patients with pernicious anemia. Gastroenterology 1982;83:204-9.

40. Borch K, Axelsson CK, Halgreen H, Damkjaer NM, Ledin T, Szesci PB. The ratio of pepsinogen A to pepsinogen C: A sensitive test for atrophic gastritis. Scand J Gastroenterol 1989;24:870-6.

41. Kekki M, Samloff IM, Varis K, Ihamaki T. Serum pepsinogen I and serum gastrin in the screening of severe atrophic corpus gastritis. Scand J Gastroenterol Suppl 1991;186:109-16.

42. Samloff IM. Pepsinogens I and II: Purification from gastric mucosa and radioimmunoassay in serum. Gastroenterology 1982;82:26-33

43. Joossens JV, Geboers J. Diet and environment in the etiology of gastric cancer. In: Levin B, Riddell RH, editors. Frontiers in gastrointestinal cancer. New York: Elsevier; 1984:168-83.

44. Boeing H. Epidemiological research in stomach cancer: Progress over the last ten years. J Cancer Res Clin Oncol 1991;117:133-43.

45. Miller AB, Berrinto F, Hill M, Pietinen P, Riboli E, Wahrendorf J. Diet in the etiology of cancer: A review. Eur J Cancer 1994;30:207-20.

46. Correa P. A human model of gastric carcinogenesis. Cancer Res 1988:48:3554-60.

47. Tsugane S, Tei Y, Takahashi T, Watanabe S, Sugano K. Salty food intake and risk of Helicobacter pylori infection. Jpn J Cancer Res 1994;85:474-8 